\title{
THMs precursor removal by an integrated process of ozonation and biological granular activated carbon for typical Northern China water
}

\author{
Mingquan Yan ${ }^{\mathrm{a}, *}$, Dongsheng Wang ${ }^{\mathrm{b}}$, Xiaona $\mathrm{Ma}^{\mathrm{b}}$, Jinren $\mathrm{Ni}^{\mathrm{a}}$, Hansong Zhang ${ }^{\mathrm{c}}$ \\ a Department of Environmental Engineering, Peking University, The Key Laboratory of Water and Sediment Sciences, Ministry of Education, Beijing 100871, China \\ b State Key Laboratory of Environmental Aquatic Chemistry, Research Center for Eco-Environmental Sciences, CAS, POB 2871, Beijing 100085, China \\ ' Safe Drinking Water Center for Ruralarea, The Ministry of Water Source, 100053, China
}

\section{A R T I C L E I N F O}

\section{Article history:}

Received 18 December 2009

Received in revised form 8 February 2010

Accepted 12 February 2010

\section{Keywords:}

Granular activated carbon (GAC)

Natural organic matter (NOM)

Resin adsorption

Trihalomethanes formation potential

(THMFP)

Ultrafiltration

\begin{abstract}
A B S T R A C T
The removal of trihalomethanes (THMs) precursor and natural organic matter (NOM) by an integrated process of ozonation and biological granular activated carbon filtration (BGAC) as a deep water treatment process was investigated in pilot-scale tests. A comparison is also made with granular activated carbon filtration (GAC). The characteristics of the THMs precursor and the THMs formation potential (THMFP) were investigated by resin adsorption and ultrafiltration. The results show that the integrated process of ozonation and BGAC $\left(\mathrm{O}_{3} / \mathrm{BGAC}\right)$ is obviously superior to GAC for the removal of the THMs precursor because a considerable synergetic effect occurs between the ozonation and the BGAC. Although ozonation can limitedly remove dissolved organic carbon (DOC), it can cut down the molecular weight of the NOM, change its polarity, decrease the THMFP, and obviously enhance the efficiency of the BGAC. The BGAC could efficiently remove the hydrophobic base (HoB), hydrophobic neutral (HoN), weakly hydrophobic acid (WHoA), and low molecular weight fraction DOC that was produced in the optimized ozonation process. However, the BGAC stage should be carefully controlled to avoid the leakage of microbes and/or the products of metabolism because it has a high risk for producing THMs in following chlorination process.
\end{abstract}

(C) 2010 Elsevier B.V. All rights reserved.

\section{Introduction}

Natural organic matter (NOM) can cause taste, odor, and color problems in potable water, and bacterial regrowth in distribution systems. More importantly, NOM is the precursor for disinfection by-products (DBPs), such as trihalomethanes (THMs) and haloactic acids (HAAs), which are found to be carcinogens [1]. The US Environmental Protection Agency (USEPA) has established more stringent maximum contaminant levels (MCLs) of 80 and $60 \mu \mathrm{g} \mathrm{L}^{-1}$ for THMs and HAAs, respectively, for finished drinking water. To prevent the production of DBPs, NOM must be efficiently removed from raw water before disinfection. However, NOM in micropolluted raw water is a mixture of humic and synthetic compounds, such as pharmaceutical compounds, detergents, pesticides, polycyclic aromatic hydrocarbons, etc. Some of these compounds are soluble, hardly biodegradable, and irremovable in conventional water treatment processes [2]. Ozonation followed by biological treatment is one of the promising processes to remove them from raw water [3-6].

\footnotetext{
* Corresponding author. Tel.: +86 $1062755914 x 81$; fax: +86 1062756526 .

E-mail address: yanmq@pku.edu.cn (M. Yan).
}

Some researchers have found that the use of ozonation in the water treatment process results in a decrease in the formation of THMs and HAAs upon subsequent chlorination [7-9]. An increase in the ozone dosages results in a concomitant decrease in the concentrations of THMs and HAAs that formed from subsequent chlorination [10-13]. However, the ozone cannot mineralize organic carbon with a traditional water treatment dose (less than $4 \mathrm{mg} \mathrm{L}^{-1}$ ); thus, a high removal of the THMs precursor cannot be expected by simple ozonation. Ozone can cleave the unsaturated bonds in aromatic moieties that are found in NOM, which makes the organic molecules smaller, more oxidized, and more biodegradable; thus, refractory NOM transforms to the biodegradable form, i.e., biodegradable dissolved organic carbon (BDOC) [14-18]. BDOC that is produced by ozonation can be removed in subsequent biological treatments. However, Volk et al. [19] and Wricke et al. [20] reported that the maximum $\mathrm{BDOC}$ production by ozonation was only around $30 \%$ of the total DOC in raw water, even if the ozone dose or reaction time was increased. The ozonation should be set to achieve treatment goals that are based not only on the characteristics of the NOM in the raw water, which optimizes biofiltration, but also on economic benefits [21,22].

The common form of biofiltration is to operate rapid filters in a biologically active mode. BGAC is the most common media in the three primary media types for hybrid biofilters, compared 
Table 1

Water quality characteristics of the water samples.

\begin{tabular}{|c|c|c|c|c|}
\hline Sample & $\mathrm{DOC}\left(\mathrm{mg} \mathrm{L}^{-1}\right)$ & Turbidity (NTU) & $\mathrm{pH}$ & Alkalinity ( $\mathrm{mg} \mathrm{L}^{-1}$ as $\mathrm{CaCO}_{3}$ ) \\
\hline Raw water & 3.80 & 8.20 & 8.40 & 200 \\
\hline Synthetic water & 4.48 & 8.93 & 7.00 & 135 \\
\hline
\end{tabular}

with sand and anthracite [23-25]. The superiority of BGAC may be related to its better attachment surface for biofilm bacteria and/or being able to absorb some of the input BDOC or organic materials that are released by microorganisms [6,26,27]. During biofiltration, pollutants that are present in the water are removed in two parallel processes: adsorption on activated carbon and biodegradation. Activated carbon was found to accelerate the decomposition of ozone into highly oxidative species, such as hydroxyl radicals $\left(\mathrm{HO}{ }^{\bullet}\right)$ [28]. The biodegradation is a result of the presence of microorganisms on the external surface and in macropores of the GAC $[6,19]$. The microorganisms use organic compounds, both dissolved in water and previously adsorbed onto the carbon, in their metabolic processes, which results in the recovery of the adsorption capacity of the GAC. As a result, the application of ozonation followed by BGAC leads to biologically stable water $[6,19,29]$.

However, there are still some doubts about the mechanisms of the NOM removal and the THMs control by the simultaneous use of ozone and BGAC. This paper studies the performance of a combination of ozonation and BGAC for removal of THMs precursor by investigating the characteristic of the NOM with resin adsorption and ultrafiltration.

\section{Materials and methods}

\subsection{Raw water}

Two kinds of water samples were used in this study. Raw water for the pilot-scale test came from the Yellow River, which is a source of water for the Tianjin water treatment plant (Tianjin, China). Synthetic water for the bench-scale test was prepared by adding a certain amount of both kaolin and a commercial humic acid (extracted from Yellow River sediment) to tap water. Table 1 presents the mean raw water and synthetic water quality characteristics.

\subsection{Bench-scale tests}

The bench-scale ozonation was performed in an airtight contactor. The ozone was generated by an ozonizer OS-IN (Mitsubishi Electric, Japan). The ozone dosage was determined through ozonedemand tests. Ten minutes after the ozone was introduced, the samples were purged with high-pressure pure nitrogen to eliminate residual $\mathrm{O}_{3}$ and to ensure the contact time. The nitrogen purge time was $10 \mathrm{~min}$. Here the ozone dosage refers to the contact dosage, which is the mean input dosage that is added to the water samples during the contact time.

\subsection{Pilot-scale tests}

The pilot plant facility has two parallel trains; train one has coagulation, dissolved air flotation (DAF), sand-filter, GAC and disinfection. Train two has coagulation, DAF, sand-filter, mid-ozone, BGAC, and disinfection. The flow rate of each system was controlled at $5 \mathrm{~m}^{3} \mathrm{~h}^{-1}$. The coagulation process was carried out with the following conditions: rapid mixing ( $t=1 \mathrm{~min}, G=756 \mathrm{~s}^{-1}$ ) and twostage flocculation (in each stage, $t=9 \mathrm{~min}, G=91.5 \mathrm{~s}^{-1}$ ). The surface loading rate of the flotation separation pond was $11 \mathrm{~m}^{3} \mathrm{~m}^{-2} \mathrm{~h}^{-1}$, the recycle ratio was $10 \%$, the saturator pressure was $0.4 \mathrm{MPa}$, and the residence time was $126 \mathrm{~s}$. The depth of the sand-filter bed was $2.7 \mathrm{~m}$, the filtration rate was $7.86 \mathrm{~m} \mathrm{~h}^{-1}$, and the sand with a 400-nm average diameter was used as filter media. Ozonation was carried out in two-stage counter-flow contactors, with a hydraulic retention time of $12 \mathrm{~min}$. The dose of ozone is $1.5-2.0 \mathrm{mg} \mathrm{L}^{-1}$. The ozone was generated by an ozonizer OZAT ${ }^{\circledR} \mathrm{CFS}-1$ (Switzerland). The flow rate of GAC/BGAC filter in both trains is controlled at $1.25 \mathrm{~m}^{3} \mathrm{~h}^{-1}$, the residence time was about $15-20 \mathrm{~min}$, and the filtration rate was $5 \mathrm{~m} \mathrm{~h}^{-1}$. Double-layer filter medias were used, granular activated carbons (ZJ15, provided by Shenhua Co., Ningxia, China) and sand $(0.5-1.0 \mathrm{~mm})$. The depths of the granular activated carbon and sand-filtration bed are $1.5 \mathrm{~m}$ and $0.5 \mathrm{~m}$, respectively. The iodine value of carbon is $1010 \pm 20 \mathrm{mg} \mathrm{g}^{-1}$, while the density of the filter media is $0.5 \mathrm{t} \mathrm{m}^{-3}$. GAC combined with ozonation is referred to as the biological granular activated carbon (BGAC) process, or biologically enhanced activated carbon process. The schematic of pilot-scale tests is shown in Fig. 1.

The details of the pilot plant have been reported earlier in the literatures $[30,31]$.

\subsection{NOM characteristics}

Hollow-fiber modules and ultrafiltration membranes (A/G Technology) with nominal molecular weight cut-offs of $30,10,3$, and $1 \mathrm{kD}$ (Kilo-Dalton) were used to sequentially fractionate dissolved organic matter (DOM). The membranes were made of cellulose derivatives with a total surface area of $24 \mathrm{~cm}^{2}$. The applied pressure through the membranes ranged from $250 \mathrm{kPa}$ to $350 \mathrm{kPa}$. The total organic carbon (TOC) of the effluent from each membrane and the TOC of the raw water were measured to determine the content of each cumulative fraction.

Amberlite XAD-8 and XAD-4 resin were used to fractionate the DOM, which follows the procedures of Thurman and Malcolm [32] and Malcolm and MacCarthy [33]. The water samples were pre-filtered with a $0.45-\mu \mathrm{m}$ pore size filter membrane to remove the particles; they were then directed to an XAD-8 packed Col-

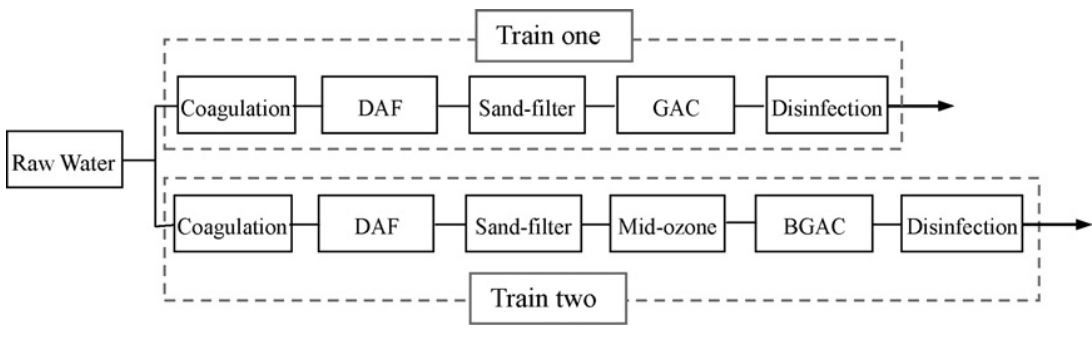

Fig. 1. The schematic of pilot-scale tests. 
umn I. The hydrophobic base and neutral (HoB\&N) fractions were absorbed by the resin. Column I was then backwashed with $0.1 \mathrm{M}$ $\mathrm{HCl}$ to release the hydrophobic base ( $\mathrm{HoB}$ ) fraction. The hydrophobic neutral ( $\mathrm{HoN})$ fraction remained in the column. The $\mathrm{pH}$ of the Column I effluent was adjusted to 2 with $\mathrm{HCl}$ before reintroduction into Column I. The second effluent of Column I contained weakly hydrophobic and hydrophilic fractions. The TOC of the first effluent from Column I minus that of the second effluent gave the hydrophobic acid (HoA) fraction. The second effluent from Column I was introduced into the XAD-4 packed Column II. The TOC that was absorbed was the weakly hydrophobic acid (WHoA) fraction, whereas the TOC of the effluent was the hydrophilic (Hi) fraction. The columns were glass chromatographic columns with PTFE caps that were $3 \mathrm{~cm}$ in diameter and $30 \mathrm{~cm}$ in height. A constant flow rate of $100 \mathrm{~mL} \mathrm{~min}^{-1}$ through each column was maintained with peristaltic pumps.

\subsection{Analytical methods}

The TOC was analyzed with a Phoenix 8000 system (TekmarDohrman Co., USA). The dissolved organic carbon (DOC) was analyzed after filtration through a $0.45-\mu \mathrm{m}$ membrane. The $\mathrm{UV}_{254}$ was measured with a spectrophotometer (UV-VIS 8500, China) after filtration through a $0.45-\mu \mathrm{m}$ membrane. The SUVA was calculated as the $\mathrm{UV}_{254}$ divided by the $\mathrm{mg} \mathrm{L}^{-1}$ DOC concentration. The turbidity was measured with a $2100 \mathrm{~N}$ Turbidimeter (Hach, USA). The alkalinity and Iodine value of the activated carbon were measured with standard methods [34]. The $\mathrm{pH}$ was measured with a pHS-3C pH meter (Shanghai, China) that was calibrated daily with $\mathrm{pH}$ buffer solutions. The input and residual ozone concentrations were determined by the sulfide iodometric method [34]. THMFP and chlorination was measured according to the Standard Methods [34] for the examination of drinking water (5710B and 6232B). The neutralized samples were buffered by a phosphate solution prior to the incubation at $25 \pm 2{ }^{\circ} \mathrm{C}$ in amber bottles with PTFE (poly-Teflon) liners. At the end of 7 days reaction period, samples with a remaining free chlorine residual of $3-5 \mathrm{mg} \mathrm{L}^{-1}$ as $\mathrm{Cl}_{2}$ were analyzed for THMs by the gas chromatography instrument (PerkinElmer Autosystem XL, USA) with an electron capture detector (ECD) and a capillary column (OV-17, $\Phi 0.32 \mathrm{~mm} \times 30 \mathrm{~m} \times 0.25 \mu \mathrm{m})$.

\section{Results and discussion}

\subsection{Performance of the integrated process of ozonation and BGAC}

The performance of the integrated process of ozonation and $\operatorname{BGAC}\left(\mathrm{O}_{3} / \mathrm{BGAC}\right)$ was investigated in the pilot-scale test after coagulation, DAF, and sand filtration, compared with the GAC. Water from the Yellow River was used. The result of the $U_{254}$ and DOC removal is shown in Fig. 2a and b, respectively. The performances of the $\mathrm{UV}_{254}$ and $\mathrm{DOC}$ removal by the $\mathrm{O}_{3} / \mathrm{BGAC}$ show some significant differences. The $\mathrm{UV}_{254}$ removal is obviously higher than the DOC removal. As high as $51 \%$ of the $\mathrm{UV}_{254}$ was removed by the $\mathrm{O}_{3} / \mathrm{BGAC}$, while only $38 \%$ of the DOC was removed. The performance of the $\mathrm{O}_{3} / \mathrm{BGAC}$ for the NOM removal could be divided into two fractions: ozonation and BGAC. For the $\mathrm{UV}_{254}$ removal, the first has a dominant contribution, which is as high as $38 \%$, while the latter is as high as $13 \%$. For the DOC removal, the trend is reversed; the latter contributes the most, as high as $38 \%$. The DOC removal by ozonation is only as high as $0.93 \%$, even negative values can be observed.

However, whether for DOC or $U_{254}$ removal, the ozonation and BGAC show some synergistic effect in the removal of the NOM. Not only is the removal of the DOC and $\mathrm{UV}_{254}$ with the $\mathrm{O}_{3} / \mathrm{BGAC}$ obviously higher than with the GAC, but also the removal of the $\mathrm{UV}_{254}$
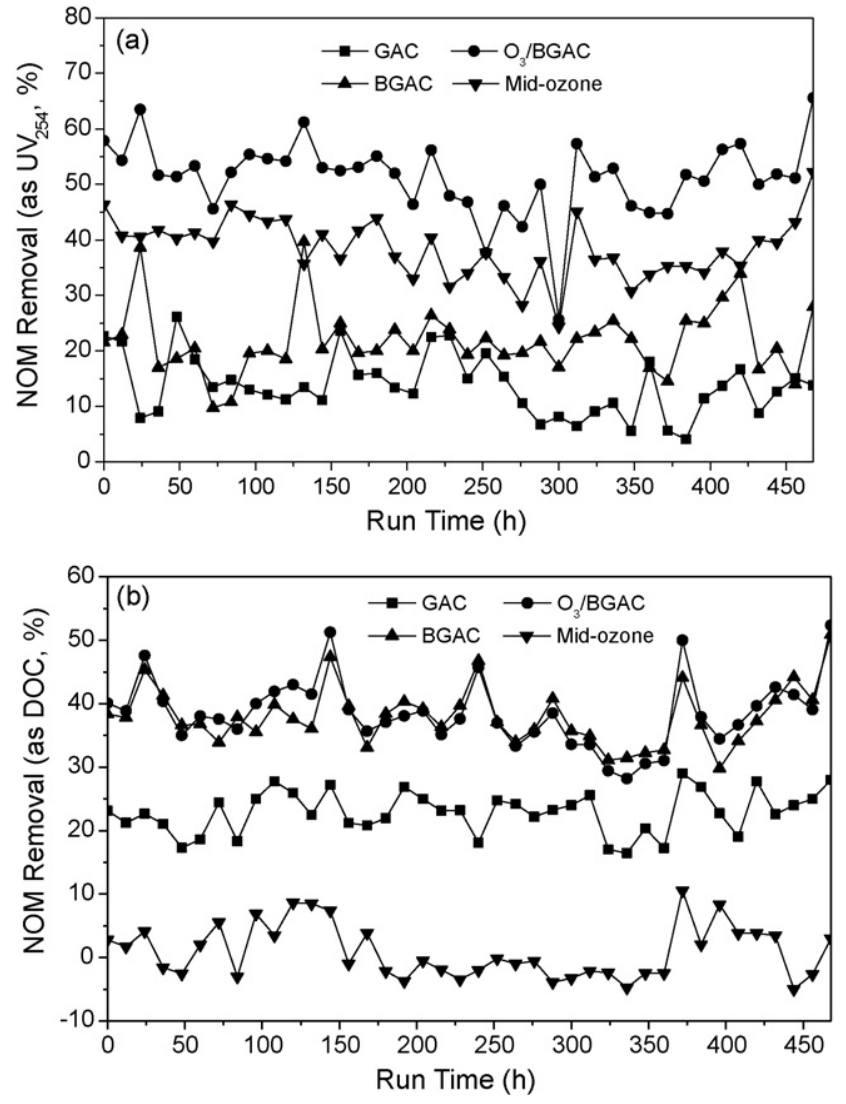

Fig. 2. Performance of integrated $\mathrm{O}_{3} / \mathrm{BGAC}$ compared with GAC for the Yellow River water. (a) $U_{254}$ removal and (b) DOC removal.

and DOC after ozonation with the BGAC (22\% and 38\%, respectively) is also higher than with the GAC ( $14 \%$ and $23 \%$, respectively).

In addition, the $\mathrm{O}_{3} / \mathrm{BGAC}$ cannot only enhance the removal of NOM but also increase the run-time and life of the filter media. The run-time of the filter media for the BGAC is as high as 7-10 days in the pilot-scale test with the Yellow River water, while it is only 2-5 days for the GAC. The carbon media can be used for more than 2 years in the BGAC, while it can only be used for 6 months in the GAC.

\subsection{Effect of the ozone on the NOM transformation}

\subsubsection{Performance of the NOM removal by ozone}

As shown in Fig. 2, the ozone plays an important role in the removal of $\mathrm{NOM} \mathrm{by} \mathrm{O}_{3} / \mathrm{BGAC}$. To investigate the NOM changes after ozonation, bench-scale tests were conducted with synthetic water that contained prescribed amounts of kaolin and humic acid. The results are shown in Fig. 3.

The $U_{254}$ removal increased significantly with an increase in the $\mathrm{O}_{3}$ dose, especially at low doses. While the DOC removal only showed a slight increase with an increase in the $\mathrm{O}_{3}$ dose. The SUVA (calculated as $\mathrm{UV}_{254}$ divided by the $\mathrm{mg} \mathrm{L}^{-1}$ DOC concentration) obviously decreased at low doses and became stable as the $\mathrm{O}_{3}$ dose was raised to $2.0 \mathrm{mg} \mathrm{L}^{-1}$. The results showed that a high DOC removal cannot be expected with a single ozonation. However, it would change the NOM's characteristics significantly. The NOM is quite complicated in nature since it contains a variety of chemical components with a large distribution of molecular weights. The source waters with a high SUVA are generally enriched in hydrophobic and high molecular weight NOM, such as ionization of carboxyl groups and humic substances [35,36]. The ozone can cleave the unsaturated bonds in the aromatic moieties that 


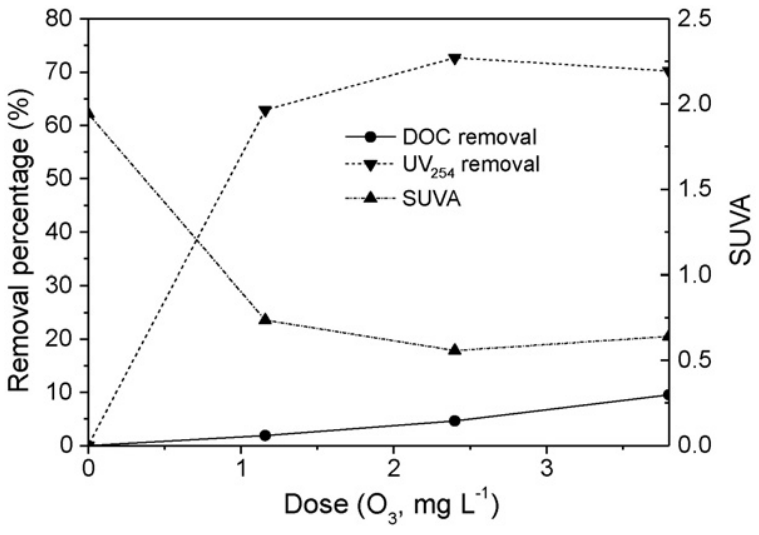

Fig. 3. Performance of NOM removal by ozonation for synthetic water.

are found in humic materials, which makes the organic molecules smaller, more oxidized, and more biodegradable; however, it cannot mineralize the organic carbon into inorganic carbon.

\subsubsection{Characteristics of the NOM after ozonation}

The DOM distributions in the synthetic water were characterized by ultrafiltration and resin adsorption before and after ozonation. The results are shown in Fig. 4.

It can be seen that the molecular weight of the DOM decreased markedly after ozonation (Fig. 4a), which became more significant at higher $\mathrm{O}_{3}$ doses. On the other hand, the percentage of intermediate molecular weight $(10-30 \mathrm{kDa}) \mathrm{DOM}$ increased with $1.1 \mathrm{mg} \mathrm{L}^{-1} \mathrm{O}_{3}$, and the range of $1-10 \mathrm{kDa}$ increased at $4.4 \mathrm{mg} \mathrm{L}^{-1}$ $\mathrm{O}_{3}$. It can also be seen that the percentage of the HoN frac-
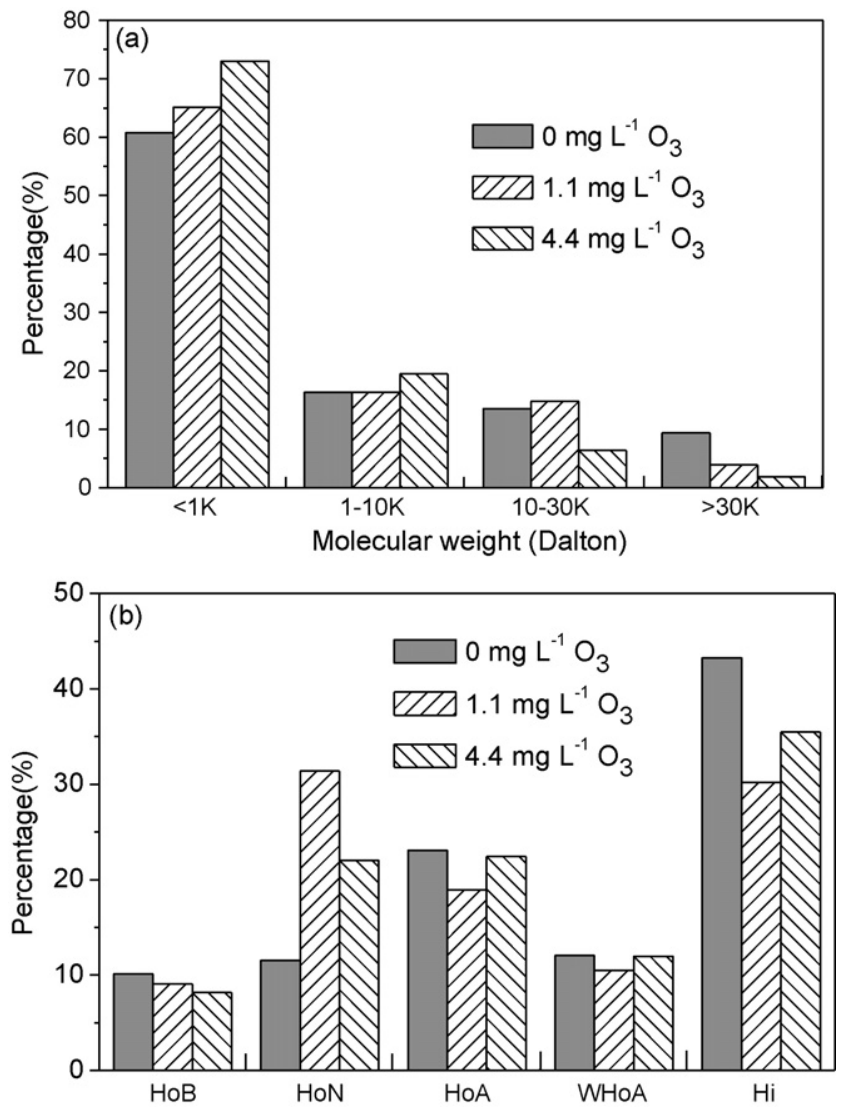

Fig. 4. Characterization of DOM before and after ozonation for synthetic water. (a) Ultrafiltration and (b) resin adsorption. tion increased after ozonation (Fig. 4b). However, more HoN was produced at a dose of $1.1 \mathrm{mg} \mathrm{L}^{-1} \mathrm{O}_{3}$ than at $4.4 \mathrm{mg} \mathrm{L}^{-1} \mathrm{O}_{3}$. The percentages of hydrophobic acid and hydrophilic DOC decreased after ozonation.

The ozone dose greatly influences the characteristics of the DOM. At a low dose, the ozone produced some hydrophobic neutral and intermediate molecular weight DOM; at a higher ozone dose, the DOM was oxidized further into a more hydrophilic and lower molecular weight DOM. The reaction mechanism of the ozone with the NOM has not been clearly understood to date. Edwards and Benjamin [37], Von Gunten [38], Swietlik [39], and Carlson et al. [40] have even identified aldehyde species (formaldehyde, acetaldehyde), glyoxal and methyl-glyoxal, ketoacids (e.g., pyruvic acid) and carboxylic acids (e.g., oxalic acid) in ozonated water. The most common ozonation by-products are aldehydes as well as shortchained carboxylic acids. Meanwhile, the ozonation by-products are affected by the ozone dose. An overdose can result in a decline in the production of aldehydes and ketones due to the oxidation of aldehydes and ketones to organic acids.

Compared to the adsorption of similar non-ozonated organic matter, the NOM with additional carboxylic groups that are produced by ozonation can be adsorbed to the GAC surface to a much larger extent. However, via potentiometric titrations, Jekel [41] and Chandrakanth and Amy [42] observed that the newly created functional groups (low molecular weight acid, such as oxalic acid) formed by ozonation that exhibited virtually no complexation capability and were weaker competing ligands, which results in a reduced density of complexation sites at a high $\mathrm{pH}$. However, the low molecular weight of the NOM after ozonation would facilitate the diffusion of the NOM in granular carbon. The GAC was very efficient process in the DOC removal, especially for the low molecular weight DOC that was produced in the ozonation stage. This fraction of the DOC could diffuse and adsorb more easily.

The ozonated NOM become more biodegradable; they can serve as substrates for microbial growth in the BGAC. The ozonation byproducts can be easily removed by biofiltration $[5,13,43]$.

\subsection{Effect of ozonation and the BGAC on the NOM and the THMFP}

\subsubsection{NOM characterization in the pilot-scale test}

The NOM in the effluences of the sand-filtration, mid-ozonation, and BGAC in the pilot-scale test with Yellow River water was characterized by resin adsorption and ultrafiltration. The results are shown in Fig. 5.

After ozonation, the molecular weight obviously decreased; molecular weights larger than $3 \mathrm{kD}$ decreased, while those lower than $3 \mathrm{kD}$ increased. The fractions of HoB, HoN, and WHoA obviously increased and the fractions of HoA and Hi decreased. This is slightly inconsistent with the results of the bench-scale test with synthetic water; however, the tendency of the NOM's changes was generally the same.

The BGAC could efficiently remove the ozonated NOM, especially for HoB, HoN, WHoA, and low molecular weight DOC that was produced in the mid-ozonation stage; this fraction of the DOC can be removed because it may be diffuse, adsorb more easily, and is biodegradable.

However, some DOCs with a molecular weight $>30 \mathrm{kD}$ were found in the effluent, which was completely removed in the former processes; the DOC with a molecular weight of 3-10 kD increased after the BGAC. The fraction of HoA also increased. This may be due to leakage of microbes and/or the products of metabolism $[5,6,25,44]$. This could lead to dramatic changes in the polarity distribution, such as the contents of hydrophobic acid and hydrophilic electrical DOC, which obviously increased $[6,44]$. It may also have a higher molecular weight. 

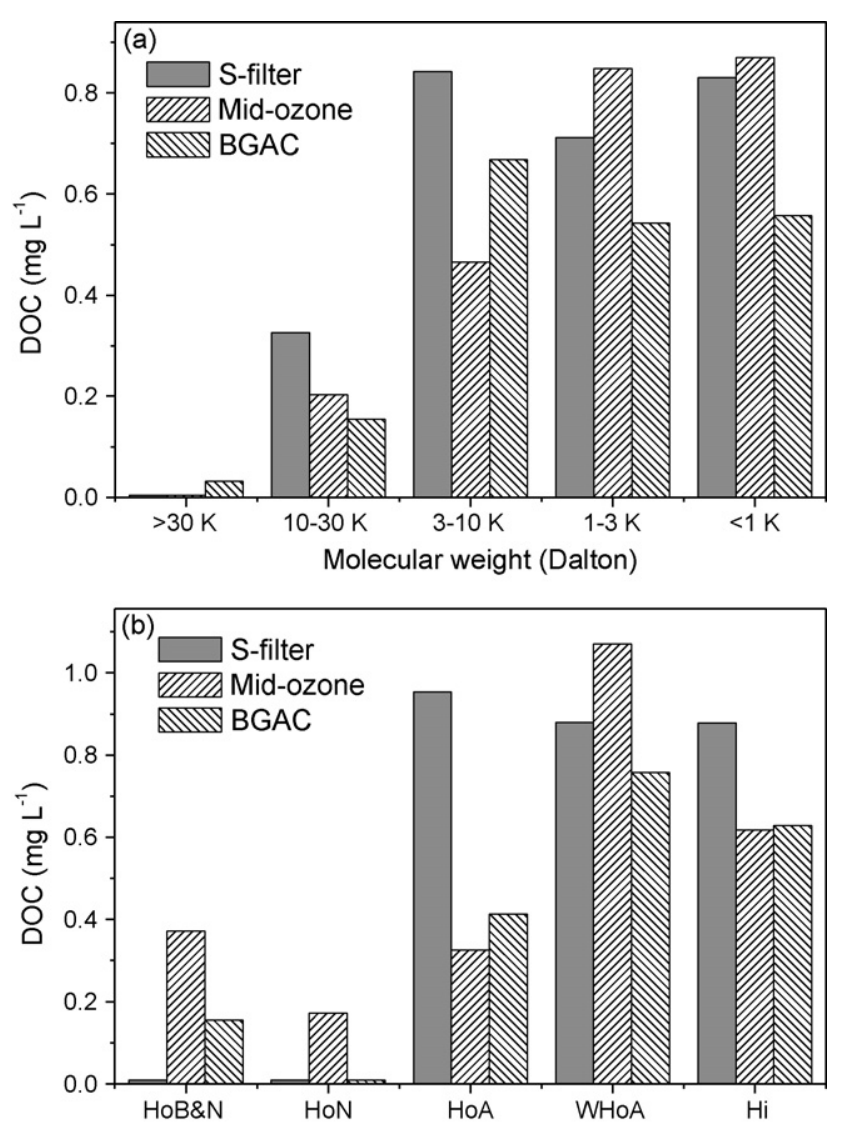

Fig. 5. The changes of NOM characterization in process of mid-ozone and BGAC for the Yellow River water. (a) Fractionated by ultrafiltration and (b) fractionated by resin adsorption.

\subsubsection{The changes to the THMFP in the process of ozonation and $B G A C$}

The THMFP of the NOM in the effluences of the sand-filtration, mid-ozonation, and BGAC in the pilot-scale test was then investigated. Although the THMFP decreased from $201.3,163.6 \mathrm{mg} \mathrm{L}^{-1}$ to $140.3 \mathrm{mg} \mathrm{L}^{-1}$, the THMFP per $\mathrm{mg}$ of DOC decreased from $74.29 \mu \mathrm{g} \mathrm{mg}^{-1}$ to $68.56 \mu \mathrm{g} \mathrm{mg}^{-1}$ after the ozone; however, it increased to $71.74 \mu \mathrm{g} \mathrm{mg}^{-1}$ after the BGAC. The ozone can decrease the THMFP of the NOM, while the BGAC increased the THMFP. The THMFP of each fraction of the NOM was characterized, the results are shown in Fig. 6.

As shown in Fig. 6a, the NOM with a medium molecular weight (3-30 kDa) has a higher THMFP than the NOM with a low molecular weight $(<3 \mathrm{kDa})$ and a high molecular weight $(>30 \mathrm{kDa})$. As shown in Fig. 5, the ozonation can cut down the molecular weight of the NOM, then the medium and high molecular weight fraction of the NOM decreased, and the low molecular weight fraction of the NOM increased. After the BGAC process, the high and medium molecular weight fraction increased, especially for the NOM with a molecular weight of 3-10 K. Therefore, the ratio of the THMFP/DOC decreased after ozonation and increased after BGAC.

As shown in Fig. 6b, the HoN and HoB that were produced after the ozone have a lower THMFP; then, the ratio of the THMFP/DOC decreased. However, after the BGAC, the THMFP of each fraction of the DOC changed greatly. In the case of the HoB and HoN, it obviously increased. This shows that the microbes and/or the products of metabolism leaked into the BGAC process with the high THMFP; this would lead to a high risk for a continued chlorination process.
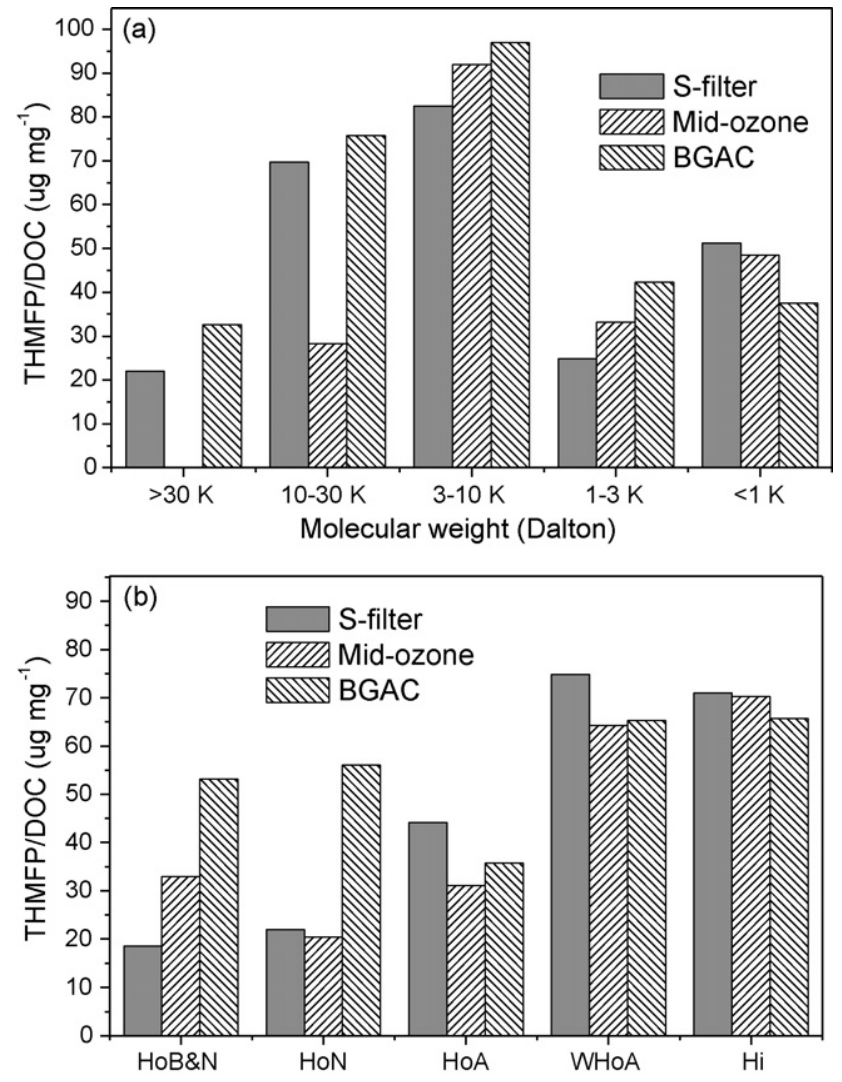

Fig. 6. The changes of THMFP of each fraction of NOM in stages of mid-ozone and BGAC for the Yellow River water. (a) Resin adsorption and (b) ultrafiltration.

In addition, this type of NOM should be BDOC; it would cause biological growth in the distribution system and should be more controlled.

\section{Conclusion}

The following conclusions can be drawn:

(1) The $\mathrm{O}_{3} / \mathrm{BGAC}$ showed obvious superiority to the GAC for removal of the THMs precursor and the NOM because a considerable synergetic effect between the ozone and the activated carbon was observed.

(2) Although the ozone can slightly remove the DOC, it can decrease the THMFP per mg of DOC and facilitate the following BGAC. The ozonation can cut down the molecular weight, the characteristic of the NOM, and make it more biodegradable, while the BGAC can efficiently remove the HoB, HoN, WHoA, and the low molecular weight fraction of the DOC that is produced in the midozone process.

(3) The BGAC process should be carefully controlled to avoid the leakage of microbes and/or the products of metabolism; it would lead to a high risk for a continued chlorination process. In addition, this type of NOM should be BDOC since it would bring bacterial regrowth into the distribution system.

\section{Acknowledgements}

The authors are very grateful to the people who provided full support for this research. This research was founded by the CNSF 50808001 and the National Key Technology R\&D Program of China (2006BAD01B03 and 2006BAD01B09); this project was also supported by the China Postdoctoral Science Foundation. 


\section{References}

[1] USEPA, Enhanced Coagulation and Enhanced Precipitative Softening Guidance Manual, EPA, Office of Water and Drinking Ground Water, Washington, DC, 1998.

[2] J.A. Leenheer, J.P. Croue, Environ. Sci. Technol. 37 (2003) 18A-26A.

[3] B.S. Ska-Sobecka, M. Tomaszewska, A.W. Morawski, Desalination 182 (2005) 151-157.

[4] B.E. Rittmanna, D. Stilwella, J.C. Garsidea, G.L. Amy, C. Spangenbergc, A. Kalinskyc, E. Akiyoshi, Water Res. 36 (2002) 3387-3397.

[5] B. Xu, N.Y. Gao, X.F. Sun, S.J. Xia, M.O. Simonnot, C. Causserand, M. Rui, H.H. Wu, Sep. Purif. Technol. 57 (2007) 348-355.

[6] N.A. Klimenko, L.A. Savchina, I.P. Kozyatnik, V.V. Goncharuk, A.O. SamsoniTodorov, J. Water Chem. Technol. 31 (2009) 220-226.

[7] E.E. Chang, P.C. Chiang, Y.W. Ko, W.H. Lan, Chemosphere 44 (2001) 12311236.

[8] X.Z. Zhang, Y. Ni, A. Van Heiningen, J. Pulp Paper Sci. 27 (2001) 279-283.

[9] S.D. Richardson, A.D. Thruston, T.V. Caughran, P.H. Chen, T.W. Collette, T.L. Floyd, K.M. Schenck, B.W. Lykins, G.R. Sun, G. Majetich, Environ. Sci. Technol. 33 (1999) 3368-3377.

[10] K.H. Lee, The effects of ozonation pathways on the formation of ketoacids and assailable organic carbon (AOC) in drinking water, Ph.D. dissertation, Michigan State University, East Lansing, MI 48823, 2001.

[11] L.A. Cipparone, A.C. Diehl Jr., G.E. Speitel, J. Am. Water Works Assoc. 89 (12) (1997) 84-97.

[12] G. Amy, C. Kuo, R. Sierka, Ozone Sci. Eng. 10 (1988) 39-54.

[13] A. Teksoy, U. Alkan, H.S. Baskaya, Sep. Purif. Technol. 61 (2008), 447-454C. Y

[14] L. Tan, G.L. Amy, J. Am. Water Works Assoc. 83 (5) (1991) 74-79.

[15] I.N. Najm, S.W. Krasner, J. Am. Water Works Assoc. 87 (1) (1995) 106115.

[16] K.M. Crosson, The use of analytical techniques for the characterization of natural organic matter (NOM) and the assessment of NOM's transformations, interactions, and removal during drinking water treatment, Ph.D. dissertation, Department of Civil and Environmental Engineering, Pennsylvania State University, USA, 2005.

[17] V. Camel, A. Bermond, Water Res. 32 (1998) 3208-3222.

[18] L.Y. Lee, H.Y. Ng, S.L. Ong, J.Y. Hu, G. Tao, K. Kekre, B. Viswanath, W. Lay, H. Seah, Water Res. 43 (2009) 3948-3955.

[19] C. Volk, P. Renner, H. Paillard, J.C. Joret, Ozone Sci. Eng. 15 (1993) 389-404.

[20] B. Wricke, H. Petzoldt, H. Heiser, K. Bornmann, NOM-removal by biofiltration after ozonation-results of a pilot plant test, in: N. Graham, R. Collins (Eds.) Advances in Slow Sand and Alternative Biological Filtration, John Wiley \& Sons, New York, 1996.
[21] K.H. Carlson, G.L. Amy, The relative importance of HLR and EBDT on the removal of BOM during biofiltration, in: Proceedings of the Water Quality Technology Conference, American Water Works Association, New Orleans, LA, 1995.

[22] B.E. Rittmann, P.L. McCarty, Environmental Biotechnology: Principles and Applications, McGraw-Hill Book Co., New York, 2001.

[23] M.W. LeChevallier, W.C. Becker, P. Schorr, R.G. Lee, J. Am. Water Works Assoc 84 (4) (1992) 136-146

[24] J.C. Wang, R.S. Summers, R.J. Miltner, J. Am. Water Works Assoc. 87 (12) (1995) 55-63.

[25] C.Y. Yin, M.K. Aroua, W.M.A.W. Daud, Sep. Purif. Technol. 52 (2007) 403-415.

[26] H.T. Chang, B.E. Rittmann, J. Water Pollut. Contl. Fed. 60 (1988) 362-368.

[27] G.E. Speitel, F.A. DiGiano, J. Environ. Eng. 113 (1987) 464-475.

[28] U. Jans, J. Hoigne, Ozone Sci. Eng. 20 (1998) 67-90.

[29] W. Nishijima, W.H. Kim, E. Shoto, M. Okada, Water Sci. Technol. 38 (6) (1998) 163-169.

[30] M.Q. Yan, Enhanced coagulation and treatment system optimization for high alkalinity and micro-polluted water, Dissertation for Ph.D., Research Center for Eco-Environmental Sciences, Chinese Academy of Sciences, Beijing, 2006 (in Chinese).

[31] M.Q. Yan, D.S. Wang, B.Y. Shi, Q.S. Wei, J.H. Qu, H.X. Tang, J. Environ. Sci. 19 (2007) 271-277.

[32] E.M. Thurman, R.L. Malcolm, Environ. Sci. Technol. 15 (1981) 463-466.

[33] R.L. Malcolm, P. MacCarthy, Environ. Sci. Technol. 20 (1986) 904-911.

[34] APHA, AWWA, WEF, Standard Methods for the Examination of Water and Wastewater, 19th ed., American Public Health Association, Washington, DC 1995, pp. 253-258.

[35] J.K. Edzwald, W.C. Beker, L. Wattier, J. Am. Water Works Assoc. 77 (4) (1985) $122-131$.

[36] C.R. O'Melia, K. Yao, K. Gray, J.E. Tobiason, Raw water quality, coagulant selection, and solid-liquid separation, in: Presented at the 1987 AWWA Annual Conference Seminar on Influence of Coagulation on the Selection, Operation, and Performance of Water Treatment Facilities, Kansas City, MO, June 14, 1987.

[37] M. Edwards, M.M. Benjamin, J. Am. Water Work Assoc. 84 (6) (1992) 56-66.

[38] U. Von Gunten, Water Res. 37 (2003) 1443-1467.

[39] J.I. Swietlik, Water Res. 38 (2004) 547-558.

[40] K.H. Carlson, G.L. Amy, J. Garside, G. Blais, Ozone-induced biodegradation and removal of NOM and ozonation byproducts in biological filters, in: Proceedings of the Slow Sand/Alternate Biological Filtration Conference, London, UK, 1996

[41] M.R. Jekel, Water Res. 20 (1986) 1535-1542.

[42] M.S. Chandrakanth, G.L. Amy, Environ. Sci. Technol. 30 (1996) 431-443.

[43] A.A. Yavich, S.J. Masten, J. Am. Water Works Assoc. 95 (4) (2003) 159-171.

[44] J.G. Jacangelo, J. DeMarco, D.M. Owen, S.J. Randtke, J. Am. Water Works Assoc. 86 (1) (1994) 64-77. 